\title{
Distribution of VDR Gene Polymorphisms Bsm-I rs1544410 and Apa-I rs7975232 among HIV/AIDS Patients from West Java
}

\author{
Hendro, ${ }^{1}$ Edhyana Sahiratmadja, ${ }^{2}$ Agnes Rengga Indrati, ${ }^{3}$ Ani Melani Maskoen ${ }^{4}$ \\ ${ }^{1}$ Faculty of Medicine Universitas Padjadjaran, Indonesia, ${ }^{2}$ Division of Biochemistry and Molecular Biology, \\ Department of Biomedical Sciences, Faculty of Medicine Universitas Padjadjaran, Indonesia, ${ }^{3}$ Department of \\ Clinical Pathology Faculty of Medicine Universitas Padjadjaran/Dr. Hasan Sadikin General Hospital Bandung, \\ Indonesia, ${ }^{4}$ Department of Oral Biology Faculty of Dentistry Universitas Padjadjaran, Indonesia
}

\begin{abstract}
Vitamin D receptor, encoded by VDR gene, mediates vitamin D functions by not only regulating calcium metabolism and homeostasis but also in regulating immune response. Polymorphisms in VDR gene may increase the progression of human immunodeficiency virus (HIV) infection into acquired immunodeficiency syndrome (AIDS). This study aimed to explore the distribution of VDR polymorphisms among HIV sero-positive patients in West Java. A cross-sectional study was performed, recruiting 96 patients infected with HIV and VDR polymorphisms were analyzed. The genotype distributions of Bsm-I among HIV-infected patients were $2.2 \%$, $18.5 \%$, and $79.3 \%$ for $\mathrm{BB}, \mathrm{Bb}$, and bb, respectively whereas the distributions of Apa-I were $54.4 \%$, 38.9\%, and $6.7 \%$ for AA, Aa and aa, respectively. The frequency of VDR polymorphisms in Bsm-I among HIV-infected patients in West Java were considered high for b allele (88.6\%), and in contrast for A allele in Apa-I that was 73.91\%. Further studies involving healthy controls are needed to explore the VDR polymorphisms distribution in general population. Moreover, a cohort study, albeit challenging, is needed to further assess the association between VDR polymorphisms and the progression of HIV infection.
\end{abstract}

Key words: Apa-I, Bsm-I, polymorphism, vitamin D Receptor, VDR gene

\section{Distribusi Polimorfisme gen VDR Bsm-I rs1544410 dan Apa-I rs7975232 pada Pasien HIV/AIDS di Jawa Barat}

\begin{abstract}
Abstrak
Reseptor vitamin D yang dikode oleh gen $V D R$ mempunyai peranan penting terhadap fungsi vitamin D; tidak hanya dalam regulasi metabolisme dan keseimbangan kalsium namun juga berperan dalam meregulasi respons imun. Polimorfisme pada gen VDR dapat meningkatkan perkembangan infeksi human immunodeficiency virus (HIV) menjadi acquired immunodeficiency syndrome (AIDS). Penelitian ini bertujuan mengetahui distribusi polimorfisme gen VDR pada pasien HIV di Jawa Barat. Penelitian ini melibatkan 96 pasien HIV dan dilakukan analisis polimorfisme gen VDR. Distribusi genotip Bsm-I pada pasien HIV di Jawa Barat adalah 2,2\%, 18,5\%, dan 79,3\% untuk BB, Bb, dan bb, secara berurutan; sedangkan pada Apa-I adalah 54,4\%, 38,9\%, dan 6,7\% untuk AA, $\mathrm{Aa}$, dan aa. Frekuensi polimorfisme pada Bsm-I pada pasien HIV di Jawa Barat tergolong tinggi pada alel b $(88,6 \%)$, dan berbanding terbalik pada dan Apa-I dengan alel A yaitu 73,91\%. Penelitian lebih lanjut yang melibatkan individu kontrol diperlukan untuk mengetahui distribusi polimorfisme gen $V D R$ pada populasi umum. Selain itu, studi kohort pada pasien HIV/AIDS diperlukan untuk menilai hubungan antara polimorfisme gen VDR terhadap progresivitas infeksi HIV.
\end{abstract}

Kata kunci: Apa-I, Bsm-I, polimorfisme, reseptor vitamin D, VDR

Corresponding Author: Edhyana Sahiratmadja, Department of Biomedical Sciences, Faculty of Medicine, Universitas Padjadjaran, Jalan Raya Bandung Sumedang, KM. 21, Sumedang, West Java, Indonesia, Email: e.sahiratmadja@unpad.ac.id 


\section{Introduction}

Acquired immune deficiency syndrome (AIDS), caused by human immunodeficiency virus (HIV) infection, is a syndrome associated with an increased risk of opportunistic infection due to an impaired immune system. ${ }^{1}$ The high prevalence of HIV/AIDS is still a vast global health issue, where Indonesia accounts for approximately 620.000 cases. $^{2,3}$

HIV infection is a chronic inflammatory disease characterized by Th1-like response. Therefore, the susceptibility to HIV infection and the rates of AIDS as a disease progression are associated with the host immune response. ${ }^{1}$ Vitamin $\mathrm{D}_{3}\left(1,25(\mathrm{OH})_{2} \mathrm{D}_{3}\right)$ is essential in the immune system modulation. ${ }^{4}$ Vitamin D interacts with its specific intracellular vitamin D receptor and forms a complex Retinoid X Receptor (RXR) that further mediates vitamin $\mathrm{D}_{3}$ functions. ${ }^{5}$ The role of vitamin $\mathrm{D}_{3}$ - VDR complex in the immune system is to inhibit the maturation of dendritic cells as well as the proliferation of T lymphocyte in promoting proinflammatory cytokine synthesis and immune response. The inhibiting effect of vitamin $\mathrm{D}$ on the immune response appears to target Th1 cells by preventing their activation and lymphokine production. Furthermore, vitamin D triggers antimicrobial pathways in host cells and activates genes that enhance the immunity. ${ }^{6}$

Vitamin $\mathrm{D}_{3}$ also plays a role in mineral metabolism, especially in regulating the calcium and skeletal homeostasis. Thus, the deficiency of vitamin D is related to skeletal diseases. ${ }^{7}$ Non-skeletal diseases such as cancer, diabetes, cardiovascular diseases, and autoimmunity may also be influenced by the deficiency of vitamin $\mathrm{D}^{8,9}$ Vitamin D deficiency is related to a higher risk of infection and poor prognosis of infectious diseases, such as tuberculosis and HIV. ${ }^{10}$

The underlying mechanisms to infection resistance and the variability observed in the rate of disease progression after infection are likely to be multifactorial, which may include the host genetic factor. VDR gene has several single nucleotide polymorphisms (SNPs) such as Bsm-I, Apa-I, and Taq-I that are found in 3' untranslated region (UTR); Cdx2 and A-1012G in 5' regulatory region, and Fok-I in the coding region. ${ }^{5}$ Bsm-I polymorphism or rs 1544410 is formed by substitution of adenine-guanine $(\mathrm{A} / \mathrm{G})$ and consists of $\mathrm{B}$ and $\mathrm{b}$ allele, whereas Apa-I or 7975232 is created by the substitution of guanine-thymine $(\mathrm{G} / \mathrm{T})$ and consists of $\mathrm{A}$ and a alleles. Interestingly, polymorphism in the 3'UTR
$V D R$ gene is associated with the mRNA stability of $V D R$ that adjusts the expression of $V D R$ and other polymorphism in $V D R$ which also shows a modulation in vitamin D-VDR complex activity. ${ }^{5}$ $V D R$ gene, which encodes vitamin $\mathrm{D}$ receptor, has various polymorphisms and the variations at the $V D R$ locus have been associated with the susceptibility and progression to several immune diseases. ${ }^{5} V D R$ polymorphism has shown to play a significant role in the susceptibility of other diseases, such as spin al7 and gynecological carcinoma. ${ }^{8}$ As for polymorphisms in VDR gene Fok-I, infected HIV patients carrying the Ff genotype has been considered prone to a faster progression to AIDS. ${ }^{11}$

The distribution of VDR polymorphisms differ across the global population. In Brazil, for example, the $B s m-I$ genotype $\mathrm{BB}, \mathrm{Bb}$, and bb are found in $16.5 \%, 50.4 \%$, and $33.1 \%$, respectively. However, in China, only BB (15.8\%) and bb (84.2\%) polymorphisms are observed. ${ }^{12,13}$ In Indonesia, the VDR polymorphism has been studied in several populations including, among others, in Batak ethnic in North Sumatera ${ }^{14}$ The difference of VDR polymorphisms in various populations has led this study to explore the distribution of $V D R$ gene polymorphisms among HIV seropositive patients in West Java. The genotype carried by the HIV seropositive patients may serve as a predictor to consider whether an individual is prone to a faster progression to AIDS.

\section{Methods}

This was a descriptive cross-sectional study on a total of 96 HIV/AIDS patients recruited from several cities in West Java in 2013. In brief, upon informed consent, genomic DNA was extracted according to the manufacturer's procedure. Single nucleotide polymorphisms of the VDR gene at rs1544410, rs7975232, rs731236 and rs 2228570 or at the restriction site of Bsm-I, Apa-I,Taq-I, and Fok-I, respectively, were analyzed (Bead Xpress Readerâ, Illumina ${ }^{a}$ ) at the Molecular Biology Laboratory of Faculty of Medicine, Universitas Padjadjaran. This genotyping system machine is able to examine a total of 48 Single Nucleotide Polymorphisms (SNPs) of the four SNPs of the VDR gene examined. In brief, DNA was activated to bind to paramagnetic samples, and hybridization was followed according to the manufacturer's protocol. Microbead code was then identified and the fluorescent signal was detected. The distribution of VDR gene 
Table 1 Clinical Characteristics of HIV/AIDS Patients in West Java

\begin{tabular}{lcc}
\hline & $\mathbf{n}$ & $\mathbf{\%}$ \\
\hline Gender & & \\
$\quad$ Male & 73 & 83.9 \\
$\quad$ Female & 14 & 16.1 \\
Risk Factor & & \\
$\quad$ IDU & 53 & 60.9 \\
$\quad$ Non-IDU & 34 & 39.1 \\
TB History & & \\
TB & 4 & 4.6 \\
$\quad$ No TB history & 81 & 93.1 \\
$\quad$ Missing data & 2 & 2.3 \\
\hline
\end{tabular}

Notes: IDU: injection drug use; TB: tuberculosis

polymorphisms was visualized in a single dot that represented individual genotype. Data generated were then analyzed (GenomeStudio ${ }^{a}$, Illumina ${ }^{\hat{a}}$ ). The distribution of $V D R$ gene polymorphisms was counted for the frequency and presented in the table.

This study was approved by the Health Research Ethics Committee of Faculty of Medicine, Universitas Padjadjaran Bandung through the issuance of the ethical clearance no. 948/UN6.KEP/EC/2018.

\section{Results}

In total, $96 \mathrm{HIV} /$ AIDS patients were initially recruited. However, data on genotype could only be retrieved from 87 patients, consisting of 73 males $(83.9 \%)$ and 14 females (16.1\%). The mean age of the patients was 30.2 years old (SD \pm 6.1$)$. These patients were mostly $(60.9 \%)$ injecting drug users (IDUs) and tuberculosis coinfection was only found in a small proportion $(4.7 \%)$ of the HIV/AIDS patients as depicted in Table 1 . From the medical record collected, the mean of CD4 count was identified to be 318.02

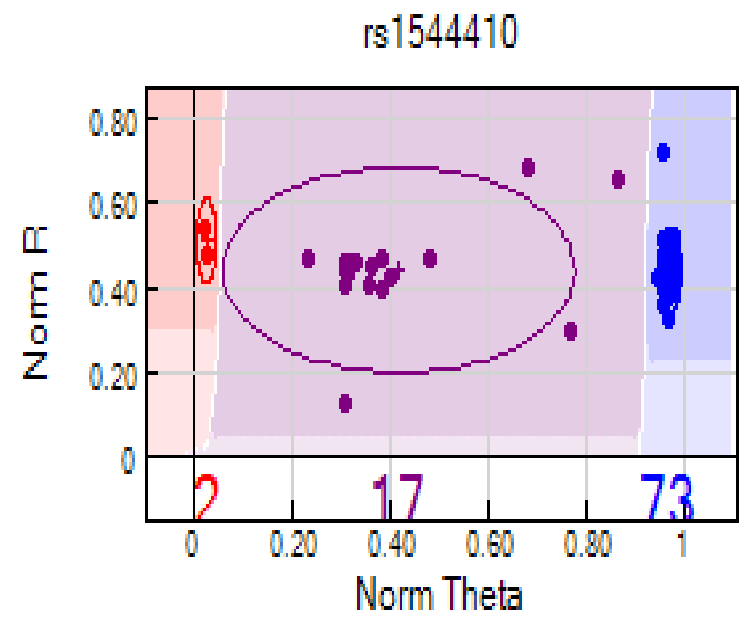

Figure 1 Distribution of rs1544410 Bsm-I VDR Gene Polymorphism in West Java as Shown Using Illumina's Genome Studio $^{\circledR}$

Every single dot represents individuals genotyped in oneplatefor 96 individuals. Pink area is designated as genotype $\mathrm{BB}$, purple area as $\mathrm{Bb}$, blue area as bb, respectively.

(SD \pm 273.1$)$. Since this was a cross-sectional study, the CD4 count could not be analyzed further for the correlation with the VDR polymorphisms result below.

The distribution of the VDR gene polymorphisms was visualized in a single dot that represented individual genotype as shown in Figures 1 and 2. Only Bsm-I and Apa-I polymorphisms were detected whereas polymorphisms of Taq-I and Fok-I were failed to be detected due to some technical error. The genotype of Bsm-I polymorphism was mostly bb (79.3\%), with the most frequent b allele of $88.6 \%$. Meanwhile, the genotype of Apa-I polymorphism was mostly AA (54.4\%), with allele A as the most prevalent $(73.9 \%)$ as depicted in Table 2.

Table 2 Distribution of Genotype and Allele of VDR Polymorphisms at Restriction Site of Bsm-I and Apa-I in HIV/AIDS Patients from West Java

\begin{tabular}{lccccc}
\hline \multicolumn{1}{c}{ VDR polymorphisms } & \multicolumn{3}{c}{ Genotype (\%) } & \multicolumn{2}{c}{ Allele } \\
\hline Bsm-I & $\mathrm{BB}$ & $\mathrm{Bb}$ & $\mathrm{bb}$ & $\mathrm{B}$ & $\mathrm{B}$ \\
& $2(2.2)$ & $17(18.5)$ & $73(79.3)$ & 11.4 & 88.6 \\
\multirow{2}{*}{ Apa $-I$} & $\mathrm{AA}$ & $\mathrm{Aa}$ & $\mathrm{aa}$ & $\mathrm{A}$ & $\mathrm{a}$ \\
& $49(54.4)$ & $35(38.9)$ & $6(6.7)$ & 73.9 & 26.1 \\
\hline
\end{tabular}




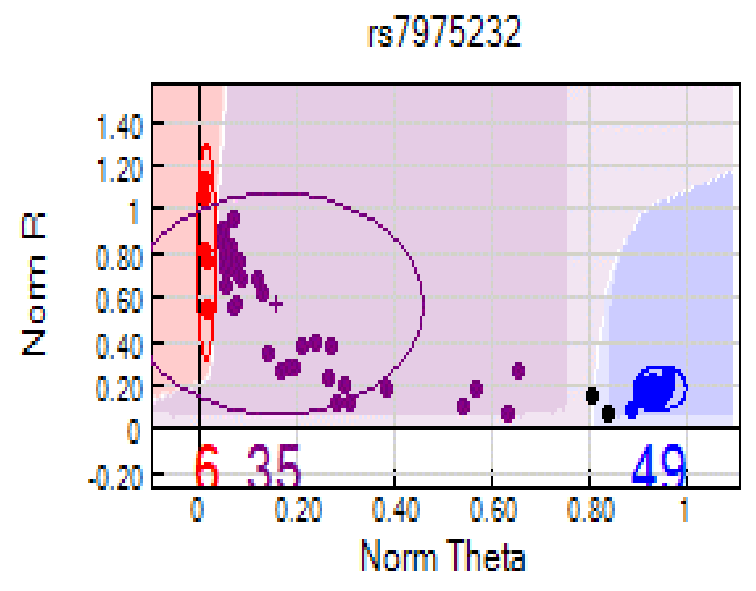

Figure 2 Distribution of rs7975232 Apa-I VDR gene polymorphism in West Java as Shown Using Illumina's Genome Studio $^{\circledR}$

Every single dot represents individuals genotyped in one plate for 96 individuals. Pink area is designated as genotype AA, purple area as Aa, blue area as aa, respectively.

\section{Discussion}

Vitamin D receptor, encoded by the VDR gene, is a nuclear receptor (NR) superfamily that has an essential function in regulating the immune system in macrophages, dendritic cells, neutrophils, B cells, natural killer (NK) cells, and T lymphocyte. ${ }^{15}$ Studies on VDR polymorphisms have shown a significant role in susceptibility to HIV and an increasing role in the progression of HIV infection to AIDS, both in adult and pediatric patients. ${ }^{16,17}$ The VDR polymorphisms across the global population have different distributions. The present study in West Java has described the distribution of VDR gene polymorphisms at rs1544410 and rs7975232 or at the restriction site of Bsm-I and Apa-I, respectively. The result in Bsm-I polymorphism in Sundanese HIV infected patients has shown a high portion of b allele $(79.3 \%)$, similar to the study on the general population of Batak people, which is another ethnic in Indonesia. ${ }^{14}$ The distribution of $B s m-I$ allele $\mathrm{b}$ is also in agreement with that of other Asian population ${ }^{13}$ but differs from the population from other continents in South America. ${ }^{12}$ It seems that the high portion of the $\mathrm{b}$ allele in the HIV-infected patients in this study also reflects the general population distribution and, thus, shows no difference. The important role of having a b allele needs to be further analyzed, for example to assess its association with the CD4 count.

Lymphocyte T CD4 has a gp120 glycoprotein structure that is associated with HIV initial infection. HIV binds with gp120 to begin its invasion and it will eventually damage the CD4 cells. ${ }^{18} \mathrm{CD} 4$ cell death, caused by HIV, is associated with caspase-3-mediated apoptosis and caspase1-mediated pyroptosis. ${ }^{18}$ Thus, individuals with $V D R$ polymorphisms may have lower CD4 counts due to the more rapid proliferation of the virus. ${ }^{15}$ Interestingly, a previous study of $V D R$ SNPs related to HIV infection has shown that $B s m-I$ and Apa-I polymorphisms have produced lower IL-10 and had a decreased lymphocyte response. ${ }^{19}$ IL-10 function as an inhibitor for HIV-1 proliferation.

In contrast, the Apa-I allele in Sundanese is mostly A (54.4\%), which is equally distributed with allele $\mathrm{a}$, and is similar to other countries in Asia, including in China ${ }^{13}$ and India. ${ }^{10}$ Again, the important result of having allele a needs further investigation. Furthermore, due to a technical problem in the laboratory, this study has failed to detect Taq-I and Fok-1 polymorphisms. Fok-1 polymorphism has been known to have a significant association with HIV/AIDS progression. ${ }^{11}$ CD4 cell count drops to below 200/uL faster in HIV infected patients with Fok-1 polymorphism or $\mathrm{Ff}$ carriers; ${ }^{11}$ therefore, the measurement of regular CD4 cell count is necessary to monitor the progression of HIV infection to AIDS when HIV-infection individual is carrying Ff genotype. Moreover, $V D R$ polymorphisms also increase phagocytosis of macrophage towards M.tuberculosis that it may affect the progression of HIV-TB patients. ${ }^{10}$

$V D R$ gene polymorphisms may have impacted in vitamin D absorption among HIV/AIDS patients and may of great interest to explore further. Vitamin D supplementation in patients infected with HIV can improve antibacterial immunity. ${ }^{20}$ Vitamin D is able to inhibit the proliferation of T lymphocyte. Therefore, by giving HIV/AIDS patients vitamin D supplementation, a protective effect may be gained due to decreasing activated immune system and HIV target cells. ${ }^{21}$

This study has encountered several limitations because it was only performed among HIV/AIDS patients that the comparison in the distribution of $V D R$ polymorphism, especially Bsm-I and Apa-I, in the general population cannot be observed and cannot be compared with healthy controls. Therefore, studies involving healthy controls in the same area are necessary. Furthermore, a cohort study is considered a better study design to explore the progression of HIV infection to 
AIDS or to assess the fall of CD4 cell count as an effect of $V D R$ polymorphisms.

To conclude, the frequency of VDR polymorphisms among HIV-infected patients in West Java is considered high for $b$ allele of Bsm-I (88.6\%) and a allele of Apa-I is common (26.1\%). VDR polymorphisms among HIVinfected patients may have a predictor value in the progression of HIV infection.

\section{References}

1. Naif HM. Pathogenesis of HIV infection. Infect Dis Rep. 2013;5(Suppl 1):26-30.

2. World Health Organization. 2015. [cited 2018 August 7]. HIV/AIDS 2015. Available from: https://www.who.int/gho/hiv/ epidemic_status/deaths_text/en/.

3. UNAIDS Indonesia 2016. [cited 2018 August 7]. Available from: https://www.unaids.org/ en/regionscountries/countries/indonesia.

4. Di Rosa M, Malaguarnera M, Nicoletti F, Malaguarnera L. Vitamin D3: a helpful immunomodulator. Immunology. 2011; 134(2):123-39.

5. Pike JW, Meyer MB. The vitamin D receptor: new paradigms for the regulation of gene expression by 1,25-Dihydroxyvitamin D3. Rheum Dis Clin North Am. 2012;38(1):1327.

6. Lake JE, Adams JS. Vitamin D in HIV-infected patients. Curr HIV/AIDS Rep. 2011;8:133141.

7. Colombini A, Brayda-Bruno M, Lombardi G, Croiset SJ, Ceriani C, Buligan C, et al. BsmI, ApaI and TaqI polymorphisms in the vitamin D receptor gene (VDR) and association with lumbar spine pathologies: An Italian casecontrol study. PLoS One. 2016;11:1-15.

8. Deuster E, Jeschke U, Ye Y, Mahner S, Czogalla B. Vitamin D and VDR in gynecological cancers-A systematic review. Int $\mathrm{J}$ Mol Sci. 2017;18 (11). pii: E2328.

9. Bae SC, Lee YH. Vitamin D receptor FokI, TaqI, and ApaI polymorphisms and susceptibility to systemic lupus erythematosus: an updated meta-analysis. Clin Rheumatol. 2018;37(6):1529-37.

10. Alagarasu K, Selvaraj P, Swaminathan S, Narendran G, Narayanan PR. 5' regulatory and $3^{\prime}$ untranslated region polymorphisms of vitamin D receptor gene in south Indian HIV and HIV-TB patients. J Clin Immunol. 2009;29:196-204.

11. Jiménez-Sousa MA, Jiménez JL, Fernández-
Rodríguez A, Brochado-Kith O, Bellón JM, Gutierrez F, et al. VDR rs2228570 polymorphism is related to non-progression to AIDS in antiretroviral therapy naïve HIVinfected patients. J Clin Med. 2019;8(3):E311.

12. Monticielo OA, Chies JAB, Longo MGF, Rucatti GG, Scalco R, Xavier RM. The role of Bsm I and Fok I vitamin D receptorgene polymorphisms and serum 25-hydroxyvitamin D in Brazilian patients with systemic lupus erythematosus. Lupus. 2012;21:43-52.

13. Huang X, Cao Z, Zhang Z, Yang Y, Wang J, Fang D. No association between Vitamin D receptor gene polymorphisms and nasopharyngeal carcinoma in a Chinese Han population. Biosci Trends. 2011;5(3):99-103.

14. Sinaga BY, Amin M, Siregar Y, Sarumpaet SM. Correlation between vitamin $D$ receptor gene FOKI and BSMI polymorphisms and the susceptibility to pulmonary tuberculosis in an Indonesian Batak-ethnic population. Acta Med Indones. 2014;46(4):275-82.

15. Laplana M, Sánchez-de-la-Torre M, Puig T, Caruz A, Fibla J. Vitamin-D pathway genes and HIV-1 disease progression in injection drug users. Gene. 2014;545(1):163-9.

16. Torres C, Sánchez de la Torre M, GarcíaMoruja C, Carrero AJ, Trujillo Mdel M, Fibla J, et al. Immunophenotype of vitamin D receptor polymorphism associated to risk of HIV-1 infection and rate of disease progression. Curr HIV Res. 2010;8(6):48792.

17. Moodley A, Qin M, Singh KK, Spector SA. Vitamin D-related host genetic variants alter HIV disease progression in Children. Pediatr Infect Dis J. 2013;32(11):1230-36.

18. Doitsh G, Galloway NLK, Geng X, Yang Z, Monroe KM, Zepeda O, et al. Cell death by pyroptosis drives CD4 T-cell depletion in HIV-1 infection. Nature. 2014;505:509-14.

19. Aguilar-Jiménez W, Zapata W, Caruz A, Rugeles MT. High transcript levels of vitamin D receptor are correlated with higher mRNA expression of human beta defensins and IL10 in Mucosa of HIV-1-exposed seronegative individuals. PLoS One. 2013;8(12):e82717.

20. Cantorna M, Snyder L, Lin YD, Yang L. Vitamin D and 1,25(OH) $)_{2}$ R Regulation of T cells. Nutrients. 2015;7(4):3011-3021.

21. Chun RF, Liu NQ, Lee T, Schall JI, Denburg MR, Rutstein RM, et al. Vitamin D supplementation and antibacterial immune responses in adolescents and young adults with HIV/AIDS. J Steroid Biochem Mol Biol. 2015;148:290-7. 